\title{
Julie Anselmini, Extase et hystérie: le «ravissement musical» dans les romans de Dumas
}

\section{Lise Sabourin}

\section{(2) OpenEdition}

10 Journals

\section{Édition électronique}

URL : http://journals.openedition.org/studifrancesi/1563

DOI : 10.4000/studifrancesi. 1563

ISSN : 2421-5856

Éditeur

Rosenberg \& Sellier

\section{Édition imprimée}

Date de publication : 1 novembre 2014

Pagination : 620

ISSN : 0039-2944

\section{Référence électronique}

Lise Sabourin, « Julie Anselmini, Extase et hystérie: le «ravissement musical» dans les romans de Dumas », Studi Francesi [En ligne], 174 (LVIII | III) | 2014, mis en ligne le 01 novembre 2014, consulté le 18 septembre 2020. URL : http://journals.openedition.org/studifrancesi/1563 ; DOI : https://doi.org/ 10.4000/studifrancesi. 1563

Ce document a été généré automatiquement le 18 septembre 2020.

\section{(c)}

Studi Francesi è distribuita con Licenza Creative Commons Attribuzione - Non commerciale - Non opere derivate 4.0 Internazionale. 


\title{
Julie Anselmini, Extase et hystérie: le «ravissement musical» dans les romans de Dumas
}

\author{
Lise Sabourin
}

\section{RÉFÉRENCE}

JULIE ANSELMINI, Extase et hystérie: le «ravissement musical» dans les romans de Dumas, in AA. Vv. La Haine de la musique, «Recherches et travaux», n. 78, textes réunis et présentés par Claude COSTE et Bertrand VIBERT, Grenoble, Université Stendhal, 2011, pp. 69-80.

1 Dumas, grand amateur de Mozart et Weber, a écrit avec Nerval le livret d'opéra Piquillo, aimé la cantatrice Caroline Ungher et fréquenté Liszt, Berlioz, Rossini: pourtant il réserve à la musique une place apparemment négative dans ses romans (Pauline 1838, Amaury 1843, Le Père La Ruine 1860, La Fille du marquis 1869 paru en 1872) qui trouvent souvent leur catastrophe par une scène de «ravissement musical» paroxystique. Dans Joseph Balsamo et Le Collier de la reine aussi, l'héroïne (en l'occurrence Andrée de Taverney) se trouve confrontée à la magie ensorcelante de la musique qui sépare son corps de son âme, comme lors des expériences magnétiques de Messmer, et la laisse subir inconsciente le viol d'un séducteur inconnu. Julie Anselmini assimile cet usage catalyseur chez Dumas à l'effet du merveilleux dans les contes: le débordement sensuel du refoulé donne accès au royaume des morts, avec tous le signes névrotiques d'une hystérie (convulsion, évanouissement, somnambulisme, catalepsie). 